\title{
EVALUATION OF TRICLOPYR TRIETHYLAMINE FOR THE CONTROL OF WETLAND WEEDS
}

\author{
P.D. CHAMPION ${ }^{1}$, T.K. JAMES ${ }^{2}$ and E.C. CARNEY ${ }^{2}$ \\ ${ }^{1}$ NIWA, PO Box 11-115, Hamilton, New Zealand \\ ${ }^{2}$ AgResearch, Ruakura Research Centre, PB 3123, Hamilton, New Zealand \\ Corresponding author: p.champion@niwa.co.nz
}

\begin{abstract}
Several experiments evaluating the susceptibility of aquatic and wetland weeds to triclopyr TEA were carried out using potted plants. Seedlings of grey willow (Salix cinerea), alder (Alnus glutinosa) and purple loosestrife (Lythrum salicaria), and cuttings of crack willow (S. fragilis), primrose willow (Ludwigia peploides), water celery (Apium nodiflorum), water cress (Nasturtium officinale) and monkey musk (Mimulus guttatus) were collected in the field and grown in cultivation. At least 2 months after potting up, triclopyr TEA was applied to run off at rates between $0.25 \%$ and $5 \% \mathrm{v} / \mathrm{v}$. This resulted in excellent control of all weeds at all rates, except for purple loosestrife, which was not controlled well at the lowest rate. Keywords: aquatic herbicide, triclopyr, Garlon 360, weed control, willows, Lythrum salicaria .
\end{abstract}

\section{INTRODUCTION}

The triethylamine (TEA) salt formulation of the herbicide triclopyr (3,5,6-trichloro-2pyridinyloxyacetic acid, Garlon ${ }^{\circledR} 360,404.5 \mathrm{~g}$ ai/litre) was registered in 2007 for aquatic plant control in New Zealand. The label for this product recommends its use as a foliar spray against alligator weed (Alternanthera philoxeroides) and parrot's feather (Myriophyllum aquaticum) and as a basal stem treatment for willows (Dow AgroSciences 2007).

Current management options for wetland weed control are limited to mechanical control and use of non-specific herbicides such as glyphosate and diquat. When used as a foliar spray, these methods often disturb existing vegetation and cause off-target damage that may lead to further weed invasion (P.D. Champion, pers. obs.). Triclopyr TEA is relatively selective, with grasses, sedges, rushes and aquatic species, such as the pondweeds (Potamogeton spp.), bulrushes (Typha spp.), Canadian pondweed (Elodea canadensis) and American eelgrass (Vallisneria americana), reported as being undamaged in areas where triclopyr was used to control susceptible species (Sprecher \& Stewart 1995; Anon 2004; Hofstra et al. 2006).

This paper presents the results of experiments using potted plants to evaluate triclopyr TEA on a range of wetland and aquatic weeds.

\section{MATERIALS AND METHODS}

Plants of grey willow (Salix cinerea), crack willow (S. fragilis), alder (Alnus glutinosa), purple loosestrife (Lythrum salicaria), monkey musk (Mimulus guttatus), watercress (Nasturtium officinale), primrose willow (Ludwigia peploides var. montevidensis) and water celery (Apium nodiflorum) were collected from the field. Grey willow, alder and purple loosestrife seedlings were collected and cuttings were made of the remaining species. Purple loosestrife seedlings were sourced from Lake Virginia, Wanganui, and Koromatua near Hamilton. All other species were collected from sites in the vicinity of Hamilton City. An exemption permit to collect and cultivate unwanted organisms under the Biosecurity Act 1993 was obtained from MAF Biosecurity New Zealand. Current unwanted organisms include grey and crack willow, purple loosestrife and primrose willow. 
The plants were grown in potting mix (Daltons Premium Mix) in the AgResearch glasshouse at Ruakura for at least 2 months prior to herbicide application, except for primrose willow, which was grown in water-filled 40 litre tubs with a bed of sand. At that stage the willows, alder and purple loosestrife were between 0.5 and $1 \mathrm{~m}$ tall, and the purple loosestrife plants were at the flower bud stage. The remaining herbaceous species were treated once they formed dense mats over their pots. Triclopyr TEA $(3,5,6$-trichloro2-pyridinyloxyacetic acid, Garlon ${ }^{\circledR} 360,404.5 \mathrm{~g}$ ai/litre) was applied to plants outside the glasshouse on 13 October 2006, 2 November 2006 or 13 February 2007, depending on the growth stage and/or successful establishment of each species. Herbicide was applied to run off at $0.25 \%$ (alder, grey willow, purple loosestrife and primrose willow only), $0.50,1.25,2.50$ and $5.00 \% \mathrm{v} / \mathrm{v}$ solutions, each with a non-ionic surfactant, Citowett at $0.025 \%$, using a knapsack sprayer. Ten replicate plants were used for each treatment, with 10 untreated plants as a control. A second herbicide application at rates of 0.5 and $0.25 \% \mathrm{v} / \mathrm{v}$ was made to untreated purple loosestrife plants on 13 February 2008. Plants were returned to the glasshouse after their foliage was dry.

Plants were monitored regularly after herbicide application. Monitoring involved visual assessment of the health of each plant compared to control plants. Death of a plant rated $100 \%$ and was applied when decay of the crown and major roots for the herbaceous plants or drying and brittleness of the entire stem of the woody plants was observed. A zero rating referred to plants indistinguishable from control plants. Intermediate scores refer to one or more plants showing some symptom of herbicide damage (e.g. $50 \%$ would relate to all plants at one rate with half the green shoots compared to the control or 5 of the 10 plants killed with the remainder comparable to control plants).

\section{RESULTS AND DISCUSSION}

Triclopyr TEA caused rapid phytotoxicity to most of these weed species, often achieving $100 \%$ brown-off and death within 7-14 days after treatment, with the level of observed damage increasing over time after herbicide application (Tables 1-4). Not all purple loosestrife plants were killed at $0.5 \%$ in the first trial. However, in the second trial, total control was obtained 2 months after treatment at $0.5 \%$ and at $0.25 \% \mathrm{v} / \mathrm{v}$.

TABLE 1: Mean health score of monkey musk and water celery plants (\% relative to control, where $100 \%$ is dead) after treatment with triclopyr on 13.10.06.

\begin{tabular}{lccccccccc}
\hline & Rate & \multicolumn{3}{c}{ Monkey musk } & & \multicolumn{3}{c}{ Water celery } \\
\cline { 3 - 5 } \cline { 8 - 10 } Treatment & $(\%)$ & 16.10 .06 & 20.10 .06 & 1.12 .06 & & 16.10 .06 & 20.10 .06 & 1.12 .06 \\
\hline Untreated & - & 0 & 0 & 0 & & 0 & 0 & 0 \\
Triclopyr & 0.5 & 30 & 40 & 100 & & 25 & 30 & 100 \\
Triclopyr & 1.25 & 58 & 78 & 100 & & 33 & 50 & 100 \\
Triclopyr & 2.5 & 73 & 92 & 100 & & 52 & 73 & 100 \\
Triclopyr & 5 & 90 & 99 & 100 & & 80 & 84 & 100 \\
& & & & & & & & \\
LSD $(\mathrm{P}<0.05)$ & & 13.4 & 9.4 & - & & 10.7 & 8.6 & - \\
\hline
\end{tabular}


TABLE 2: Mean health score of purple loosestrife plants (\% relative to control, where $100 \%$ is dead) after treatment with triclopyr on 13.10 .06 and 13.2.07.

\begin{tabular}{llccccccc}
\hline Treatment & $\begin{array}{l}\text { Rate } \\
(\%)\end{array}$ & 16.10 .06 & 20.10 .06 & 1.12 .06 & 9.1 .07 & 6.3 .07 & $6.3 .07^{1}$ & $10.4 .07^{1}$ \\
\hline Untreated & - & 0 & 0 & 0 & 0 & 0 & 0 & 0 \\
Triclopyr & 0.25 & - & - & - & - & - & 99 & 100 \\
Triclopyr & 0.5 & 19 & 25 & 89 & 96 & 88 & 99 & 100 \\
Triclopyr & 1.25 & 43 & 64 & 100 & 100 & 100 & 100 & 100 \\
Triclopyr & 2.5 & 47 & 74 & 100 & 100 & 100 & 100 & 100 \\
Triclopyr & 5 & 67 & 88 & 100 & 100 & 100 & 100 & 100 \\
& & & & & & & & \\
LSD $(\mathrm{P}<0.05)$ & & 19.7 & 23.0 & - & - & - & - & - \\
\hline
\end{tabular}

${ }^{1}$ Second experiment.

TABLE 3: Mean health score of watercress and crack willow plants ( $\%$ relative to control, where $100 \%$ is dead) after treatment with triclopyr on 2.11.06.

\begin{tabular}{|c|c|c|c|c|c|c|c|c|}
\hline \multirow[b]{2}{*}{ Treatment } & \multirow{2}{*}{$\begin{array}{l}\text { Rate } \\
(\%)\end{array}$} & \multicolumn{3}{|c|}{ Water cress } & \multicolumn{4}{|c|}{ Crack willow } \\
\hline & & 6.11 .06 & 1.12 .06 & 13.2.07 & 6.11 .06 & 1.12 .06 & 13.2.07 & 10.4 .07 \\
\hline Untreated & - & 0 & 0 & 0 & 0 & 0 & 0 & 0 \\
\hline Triclopyr & 0.5 & 60 & 88 & 100 & 48 & 92 & 98 & 100 \\
\hline Triclopyr & 1.25 & 60 & 90 & 100 & 70 & 100 & 100 & 100 \\
\hline Triclopyr & 2.5 & 80 & 95 & 100 & 82 & 100 & 100 & 100 \\
\hline Triclopyr & 5 & 80 & 98 & 100 & 80 & 100 & 100 & 100 \\
\hline $\operatorname{LSD}(\mathrm{P}<0.05)$ & & - & 4.6 & - & 8.5 & - & - & - \\
\hline
\end{tabular}

TABLE 4: Mean health score of grey willow, primrose willow and alder plants (\% relative to control, where $100 \%$ is dead) after treatment with triclopyr on 13.2.07.

\begin{tabular}{|c|c|c|c|c|c|c|c|}
\hline \multirow[b]{2}{*}{ Treatment } & \multirow{2}{*}{$\begin{array}{c}\text { Rate } \\
(\%)\end{array}$} & \multicolumn{2}{|c|}{ Grey willow } & \multicolumn{2}{|c|}{ Primrose willow } & \multicolumn{2}{|c|}{ Alder } \\
\hline & & 6.3 .07 & 10.4 .07 & 6.3 .07 & 10.4 .07 & 6.3 .07 & 10.4 .07 \\
\hline Untreated & - & 0 & 0 & 0 & 0 & 0 & 0 \\
\hline Triclopyr & 0.25 & 98 & 100 & 98 & 100 & 97 & 100 \\
\hline Triclopyr & 0.5 & 100 & 100 & 100 & 100 & 98 & 100 \\
\hline Triclopyr & 1.25 & 100 & 100 & 100 & 100 & 100 & 100 \\
\hline Triclopyr & 2.5 & 100 & 100 & 100 & 100 & 100 & 100 \\
\hline Triclopyr & 5 & 100 & 100 & - & - & 100 & 100 \\
\hline $\operatorname{LSD}(\mathrm{P}<0.05)$ & & - & - & - & - & - & - \\
\hline
\end{tabular}


Susceptibility of young cultivated plants to herbicide application is likely to be much greater than plants growing in the field so field trials are currently underway to investigate control of grey willow (South Taupo Wetland), alder (Waikato River), purple loosestrife (Cockayne Reserve, Christchurch) and water celery (Waikato River).

Other herbicides registered in New Zealand for use where contamination of water may occur are diquat and some formulations of glyphosate. Diquat is a contact herbicide and is ineffective as a foliar spray against many of the wetland weeds tested, especially woody species (P.D. Champion, pers. obs.), while glyphosate is effective and is currently used for aerial willow control (Champion 2006). Glyphosate is less selective and can damage non-target plants such as sedges, grasses and rushes that are often dominant vegetation components in unimpacted wetlands. However, it has been used successfully both as a foliar application where willows form a dense canopy over desirable species and also for stem injection or cut stump treatment (Champion 2006). Triclopyr TEA appears to provide similar control of broadleaf wetland weeds as glyphosate but is much more selective in action than glyphosate, with limited damage to non-target sedges, grasses and rushes (Champion et al. 2008). This product is seen as a useful addition to the range of weed control options, providing selective control of most broadleaf wetland and emergent aquatic weeds.

\section{ACKNOWLEDGEMENTS}

The authors would like to thank the Department of Conservation for funding this project and also Ian Popay for assistance with trial design.

\section{REFERENCES}

Anon. 2004. Environmental impact statement (EIS) for permitted use of triclopyr. Washington State, Dept of Ecology Publication, Water Quality Program Publication No. 04-10-018. 115 pp.

Champion PD 2006. Evaluation of willow control at Kopuatai, Hauraki Plains, Waikato: January 2005. NIWA Client Report HAM2006-022, NIWA, Hamilton, New Zealand. 8 pp.

Champion PD, James TK, Carney E 2008. Safety of triclopyr triethylamine to native wetland species. New Zealand Plant Protection 61: 378-383.

Dow AgroSciences 1999. Garlon ${ }^{\circledR}$ 3A Herbicide. Specimen Label. USE EPA Reg. No. 62719-37.

Dow AgroSciences 2007. Garlon 360 Herbicide Label. Dow AgroSciences NZ Ltd, New Plymouth, New Zealand.

Gabor TS, Haagsma HR, Murkin HR, Armson E 1995. Effects of triclopyr amine on purple loosestrife and non-target plants in south-eastern Ontario, Canada. Journal of Aquatic Plant Management 33: 48-50.

Hofstra DE, Champion PD, Dugdale AM 2006. Herbicide trials for the control of parrot's feather. Journal of Aquatic Plant Management 44: 13-18.

SePRO 2002. Renovate ${ }^{\circledR} 3$ Herbicide. Specimen Label. USE EPA Reg. No. 62719-37-67690.

Sprecher SL, Stewart AB 1995. Triclopyr effects on peroxidase activity in target and non-target aquatic plants. Journal of Aquatic Plant Management 33: 43-47. 